Title:

\title{
Investigation of vitamin D receptor polymorphisms in amyotrophic lateral
} sclerosis

Nóra Török $^{\mathrm{a}}$, Rita Török ${ }^{\mathrm{a}}$, Péter Klivényi ${ }^{\mathrm{a}}$, József Engelhardt ${ }^{\mathrm{a}}$, László Vécsei ${ }^{\mathrm{a}, \mathrm{b}}$

${ }^{\text {a }}$ Department of Neurology, Faculty of Medicine, Albert Szent-Györgyi Clinical Centre, University of Szeged, 6 Semmelweis street, H-6725 Szeged, Hungary

${ }^{\mathrm{b}}$ MTA-SZTE Neuroscience Research Group, 6 Semmelweis street, H-6725 Szeged, Hungary

Key words: amyotrophic lateral sclerosis, ApaI, neurogenetics, VDR gene

Abbreviated title: VDR gene polymorphisms in ALS

Corresponding author:

László Vécsei MD, PhD, DSc

Department of Neurology, Faculty of Medicine, University of Szeged,

6 Semmelweis u., H-6725 Szeged,

Hungary

Tel:+36 6254471377

Fax:+36 62545597

email: vecsei.laszlo@med.u-szeged.hu 
Abstract

\section{BACKGROUND:}

Amyotrophic lateral sclerosis (ALS) patients manifest aberrations in the vitamin D-endocrine system, with a vitamin D deficiency.

Genetic investigations have identified those proteins which link vitamin D to ALS pathology: major histocompatibility complex class II molecules, toll-like receptors, poly(ADP-ribose) polymerase-1, haeme oxygenase-1, the reduced form of nicotinamide adenine dinucleotide phosphate and calcium-binding proteins. Vitamin D additionally impacts ALS through cellsignalling mechanisms: glutamate, matrix metalloproteinases, the $\mathrm{Wnt} / \beta$-catenin signalling pathway, mitogen-activated protein kinase pathways, prostaglandins, reactive oxygen species and nitric oxide synthase, but its role has been only poorly investigated.

\section{OBJECTIVE:}

Our aim was to investigate vitamin D receptor (VDR) gene single nucleotide polymorphisms (SNPs) in an ALS population. This gene encodes the nuclear hormone receptor for vitamin D3.

\section{MATERIALS AND METHODS:}

75 consecutive sporadic ALS patients ( 20\% of the Hungarian ALS population) and 97 healthy controls were enrolled to investigate the possible effects of the different VDR alleles. A restriction fragment length polymorphism technique was utilized for allele discrimination.

\section{RESULTS:}

One of the four investigated SNPs was associated with the disease, but none of the alleles of these SNPs influenced the age at disease onset. The ApaI A allele was more frequent in the ALS group than in the control group, and may be an ALS risk factor.

\section{CONCLUSIONS:}


This is the first verification of the genetic link between ALS and VDR. However, further studies are needed to confirm these findings.

Key words: amyotrophic lateral sclerosis, ApaI, neurogenetics, VDR gene Abbreviated title: VDR gene polymorphisms in ALS

Abbreviations:

ALS: amyotrophic lateral sclerosis

SNP: single nucleotide polymorphism

VDR: vitamin D receptor

MS: multiple sclerosis

PD: Parkinson's disease

AD: Alzheimer's disease 


\section{Introduction}

Amyotrophic lateral sclerosis (ALS) is a devastating disease in which the upper (cortical) and lower (spinal and ponto-bulbar) motor neurones undergo relentless degeneration resulting in death within several months or years. There is apparently no cure for it; currently the only effective treatment (Riluzole) (1) leads to merely a modest slowing of the disease progression. ALS is a rare disease, with a mean incidence of $2.8 / 100000$, and a mean prevalence of 5.40/100 000 in Europe (2).

Only $10 \%$ of the cases are classified as familial, with the remaining $90 \%$ as sporadic (3). A genetic aetiology plays a role in $\sim 65 \%$ of the familial cases and about $\sim 11 \%$ of the sporadic cases (3). The high-risk causative genes and low-risk susceptibility genes have been well surveyed in two reviews $(3,4)$.

Genetic investigations have contributed to a clarification of the mechanisms and signalling routes involved in the aetiology of the disease: glutamate excitotoxicity, damage by free radicals, a mitochondrial dysfunction, intracellular protein aggregation, excessive poly(ADPribose) polymerase activation, autoimmune inflammatory processes and the accumulation of intracellular calcium.

The rise in the level of intracellular calcium in the motor neurones is a common denominator leading to cell death in ALS and its experimental animal models, as a result of glutamate excitotoxicity or damage by free radicals or autoantibodies. One of the putative causes of the vulnerability of the motor neurones in the disease is their low levels of calcium-binding proteins (parvalbumin and calbindin-D28K), which can be elevated by gene therapy in experimental animals (5) and by vitamin D supplementation $(6,7)$.

Vitamin D is synthesized from its prohormone in the skin in response to exposure to sunlight. Its active form, $1 \alpha-25-(\mathrm{OH}) 2 \mathrm{D}$ is bound to the vitamin $\mathrm{D}$ nuclear receptor (VDR) and modulates the transcription of several genes and mineral ion homeostasis. Vitamin D 
regulates the serum calcium level, which may modify immune functions (8). It has been localized to neurones and glial cells. Genes which encode the enzymes in the metabolization of this hormone are also found in the brain. Vitamin D is additionally responsible, among others, for the biosynthesis of neurotrophic factors, inducible nitric oxide synthase and increased glutathione levels, all of which play a part in the pathomechanisms of ALS and other neurodegenerative diseases. In general, vitamin D can reduce the inflammatory reaction, which is a significant contributor in neurodegeneration. The roles of the possible genetic and cellular signalling mechanisms of vitamin D in ALS, and particularly in its G93A transgenic mouse model, have been extensively reviewed by Long and Nguyen (9).

The gene is located on the $12 \mathrm{q} 13.11$ chromosome region encoding the nuclear hormone receptor for vitamin D3. Associations have been published between VDR polymorphism and various neurological disorders, but only limited data are available as concerns ALS.

In light of the above, we set out to investigate single nucleotide polymorphisms (SNPs) of the VDR gene in ALS in a Hungarian cohort. 


\section{Patients and Methods}

\subsection{ALS patients and controls}

All the study participants provided their written informed consent. 75 unrelated ALS patients and 97 healthy controls were enrolled for analysis of the possible effects of four SNPs of the VDR gene: rs 1544410 (BsmI), rs7975232 (ApaI), rs731236 (TaqI) and rs2228570 (FokI). The ALS and control groups did not differ from each other in sex ratio $(\mathrm{p}=0.976)$ or mean age $(\mathrm{p}=0.935)$. The ALS group consisted of 47 females and 28 males; their average age was $60.3 \pm 11.0$ years, and their average age at the onset of the disease was $58.9 \pm 11.8$ years. The age at onset was determined from the medical records and the cases were categorized as earlyonset (diagnosed $\leq 60$ years) or late-onset (diagnosed $>60$ years) ALS (the median of the age at onset was 60 years). The diagnosis was established according to the El-Escorial criteria (10). The control group comprised 97 healthy volunteers, 61 of whom were females and 36 were males, with an average age of $60.1 \pm 11.3$ years. The sociodemographic data are summarized in Table 1. The study protocol was approved by the Medical Research Council Scientific and Research Ethics Committee (47066-3/2013/EKU (556/2013)) and was in full accordance with the Helsinki Declaration. Blood samples were collected at the Department of Neurology.

\subsection{Methods}

\subsubsection{DNA isolation}

Genomic DNA was isolated from peripheral blood by the standard desalting method developed by Miller et al. (11). The purified genomic DNA was stored at $-20{ }^{\circ} \mathrm{C}$ at the biobank of the Department of Neurology until further use (biobank licence: Regional Human Biomedical Research Ethics Committee: 135/2008). 


\subsubsection{Genotyping}

Three of the four investigated SNP are intron variants and one is a missense change in the genome.

rs1544410 (BsmI)

For amplification of the DNA region near the intronic rs1544410 SNP, the following primers were designed: forward primer: 5'- CAA CCA AGA CTA CAA GTA CCG CGT CAG TGA -3', and reverse primer: 5'- AAC CAG CGG GAA GAG GTC AAG GG -3'. For allele discrimination, $10 \mathrm{U} / \mu \mathrm{l}$ of the enzyme Mva1269I (BsmI) (Thermo Scientific) was applied according to the manufacturer's recommendation.

PCR amplification was carried out at $95{ }^{\circ} \mathrm{C}$ for $5 \mathrm{~min}$, followed by 44 cycles of $95{ }^{\circ} \mathrm{C}$ for 30 s, and then $60{ }^{\circ} \mathrm{C}$ for $30 \mathrm{~s}, 72^{\circ} \mathrm{C}$ for $1 \mathrm{~min} ; 72^{\circ} \mathrm{C}$ for $5 \mathrm{~min}$.

rs731236 (TaqI)

For amplification of the intronic rs731236 SNP, the following primers were used: forward primer: 5'- CAG AGC ATG GAC AGG GAG CAA -3', and reverse primer: 5'- CAC TTC GAG CAC AAG GGG CGT TAG C -3'. For separation of the alleles, $10 \mathrm{U} / \mu \mathrm{l}$ of the enzyme TaqI (Thermo Scientific) was applied according to the manufacturer's recommendation.

PCR amplification was carried out at $95{ }^{\circ} \mathrm{C}$ for $5 \mathrm{~min}$, followed by 44 cycles of $95{ }^{\circ} \mathrm{C}$ for 30 $\mathrm{s}$, and then $60^{\circ} \mathrm{C}$ for $30 \mathrm{~s}, 72^{\circ} \mathrm{C}$ for $1 \mathrm{~min} ; 72^{\circ} \mathrm{C}$ for $5 \mathrm{~min}$.

rs2228570 (FokI)

For discrimination of the missense SNP at rs2228570 from the VDR gene, the following primers were consumed: forward primer: 5'- AGC TGG CCC TGG CAC TGA CTC TGC TCT -3', and reverse primer: 5'- ATG GAA ACA CCT TGC TTC TTC TCC CTC -3'. For 
allele discrimination, $10 \mathrm{U} / \mu \mathrm{l}$ of the enzyme BseGI (BtsCI) (Thermo Scientific) was used according to the manufacturer's recommendation.

PCR amplification was carried out at $95{ }^{\circ} \mathrm{C}$ for $5 \mathrm{~min}$, followed by 44 cycles of $95{ }^{\circ} \mathrm{C}$ for 30 $\mathrm{s}$, and then $60^{\circ} \mathrm{C}$ for $30 \mathrm{~s}, 72^{\circ} \mathrm{C}$ for $1 \mathrm{~min} ; 72^{\circ} \mathrm{C}$ for $5 \mathrm{~min}$.

rs7975232 (ApaI)

For the allele discrimination of the intronic SNP at rs7975232 on chromosome 12, the following primers were applied: forward primer: 5'- CAG AGC ATG GAC AGG GAG CAA -3', and reverse primer: 5'- CAC TTC GAG CAC AAG GGG CGT TAG C -3'. For the allele discrimination, $10 \mathrm{U} / \mu \mathrm{l}$ of the enzyme ApaI (Thermo Scientific) was used according to the manufacturer's recommendation.

PCR amplification was carried out at $95{ }^{\circ} \mathrm{C}$ for $5 \mathrm{~min}$, followed by 44 cycles of $95{ }^{\circ} \mathrm{C}$ for 30 $\mathrm{s}$, and then $60{ }^{\circ} \mathrm{C}$ for $30 \mathrm{~s}, 72{ }^{\circ} \mathrm{C}$ for $1 \mathrm{~min} ; 72^{\circ} \mathrm{C}$ for $5 \mathrm{~min}$.

The PCR experiments were performed with a BioRad CFX96 C1000 real-time thermal cycler machine. After the PCR, the samples were digested with the appropriate enzymes and the resulting restriction fragments were separated according to their lengths by gel electrophoresis (Figure 1). The agarose gels were 2\% (3 g agarose (SeaKem LE agarose) and $150 \mathrm{ml} 1 \mathrm{x}$ TBE buffer (diluted from TBE buffer 10x from Applichem) with $15 \mu$ l ethidium-bromide (Sigma, $(500 \mu \mathrm{g} / \mathrm{ml}))$, the applied voltage was $120 \mathrm{~V}$. We used Gene Ruler $50 \mathrm{bp}$ (left side of the gels) and the $100 \mathrm{bp}$ (right side of the gels) DNA ladders from the Thermo Scientific. The separated alleles of the TaqI SNP were C allele (293 bp, 201 bp, 7 bp) and T allele (494 bp, 7 bp). In case of ApaI SNP the separated alleles were C allele (284 bp, $217 \mathrm{bp}$ ) and A allele (501 bp). The alleles of the FokI SNP were C allele (267 bp) and T allele (169 bp, 96 bp). The last investigated VDR SNP was BsmI with A allele (822 bp) and G allele (646 bp and 176 bp). 


\subsubsection{Statistical methods}

SPSS software version 20.0 was used for evaluation of the data. The chi-square test was utilized for comparisons of the distribution of alleles and genotypes, and the t-test for comparisons of the averages of the two groups. Odds ratio (OR) and 95\% confidence intervals (CI) were calculated to detect the association between the VDR and the risk of ALS. A p value of $<0.05$ was considered significant.

The observed genotype frequencies in the control and ALS groups were in accordance with the Hardy-Weinberg equilibrium. 


\section{Results}

rs1544410 (BsmI) SNP

This SNP, localized in the intronic segment of the VDR gene, is an A/G change. The genotype distribution in the ALS group was 9 AA, 35 AG and $31 \mathrm{GG}$, and that in the control group was $19 \mathrm{AA}, 37 \mathrm{AG}$ and $41 \mathrm{GG}$. The allele frequencies in the two groups were similar (Table 2). This SNP variant is not associated with the disease (genotype: $p=0.327$, allele frequency: $\mathrm{p}=0.527$ ) or with the age at disease onset (genotype $\mathrm{p}=0.244$ ). Moreover, no significant difference was found between this SNP and gender in the ALS group $(p=0.074)$.

rs731236 (TaqI) SNP

This intronic variant of the VDR gene is a C/T change. The genotype distribution was $9 \mathrm{CC}$, $34 \mathrm{CT}$ and 32 homozygote TT in the patient group and $18 \mathrm{CC}, 38$ heterozygote and $41 \mathrm{TT}$ in the control group. The allele frequency results: $35 \% \mathrm{C}$ allele in the ALS group vs $38 \% \mathrm{C}$ allele in the control group, and $65 \% \mathrm{~T}$ allele in the patient vs $62 \% \mathrm{~T}$ allele in the control group. This SNP variant is not associated with the disease (genotype: $p=0.462$, allele frequency $\mathrm{p}=0.507$ ) or with the age at disease onset (genotype $\mathrm{p}=0.328$ ) and no significant difference was observed in the male to female ratio $(\mathrm{p}=0.134)$ (Table 2).

rs2228570 (FokI) SNP

This SNP of the VDR gene is a missense mutation $(\mathrm{C} / \mathrm{T})$, which affects the structure and function of the encoded protein (12). The two variants of this exonic SNP code for structurally different receptor proteins. The wild-type, C allele codes a 424-amino acid protein, while the $\mathrm{T}$ allele codes a 427 -amino acid receptor. These two receptors exhibit different efficiencies of VDR binding with transcription factor II B (12), and hence have different abilities to induce the transcription of vitamin D-dependent genes. Our results indicate the lack of an association between rs2228570 and ALS (genotype: $p=0.801$, allele 
frequency $\mathrm{p}=0.542)$ and the mutation does not affect the age at disease onset $(\mathrm{p}=0.341)$ or the gender distribution in the ALS group (genotype $\mathrm{p}=0.982$ ) (Table 2).

$$
\text { rs7975232 (ApaI) SNP }
$$

This intronic variant of the VDR gene is an A/C change. The genotype distribution in the ALS patient group was $25 \mathrm{AA}, 43 \mathrm{AC}$ and $7 \mathrm{CC}$ and in the control group $28 \mathrm{AA}, 40 \mathrm{AC}$ and $29 \mathrm{CC}$. The allele frequencies were $62 \% \mathrm{~A}$ allele and $38 \% \mathrm{C}$ allele in the patient group and 49.5\% $\mathrm{A}$ and $50.5 \% \mathrm{C}$ in the control group (Table 2).

There was a significant difference in genotype distribution between the patient and control groups $\left(\chi^{2}=11.09 ; \mathrm{p}=0.004\right)$. The frequency of the genotype with $\mathrm{A}(\mathrm{AA}+\mathrm{AC})$ vs $\mathrm{CC}$ was significantly higher among the ALS patients as compared with the controls $(\chi 2=10.807, \mathrm{df}=1$, $\mathrm{p}=0.001$, OR:4.143 and 95\% CI=1.699-10.100) (Figure 2). Additionally, the A allele proved to be significantly associated with the ALS group $(\chi 2=5.352, \mathrm{df}=1, \mathrm{p}=0.021, \mathrm{OR}=0.600,95 \%$ $\mathrm{CI}=1.080-2.569)$.

The investigated two alleles had no effect on the age at disease onset (genotype $p=0.289$ ) and there was no sifnificant difference between this SNP and gender $(\mathrm{p}=0.327)$ in the ALS group (Table 2).

To summarize these results, one of the four investigated SNPs was associated with ALS (ApaI), but none of them affected the age at the onset of the disease and there were no statistical differences in the gender ratio (Table 2). 


\section{Discussion}

Earlier reports revealed that the 25-hydroxyvitamin D levels are decreased in various neurological disorders, including multiple sclerosis (MS) $(13,14)$, Alzheimer's disease (AD) $(15,16)$ and Parkinson's disease (PD) $(17,18)$. However, there have been only a few studies of the possible role of vitamin D in ALS (6, 7, 19-21).

A subnormal serum level of 25-hydroxyvitamin D was measured in a group of ALS patients (22). Supplementation which ensured at least a low level in the normal range resulted in only a slight slowing-down in disease progression as measured by the ALSFRS-R score decline during a 9-month period (6). Another report demonstrated that chronic vitamin D treatment upregulates the VDR mRNA level in cultured rat cortical neurones during neurotoxicity by glutamate (23). ALS shares pathophysiological similarities with neurodegenerative diseases such as MS, AD and PD, e.g. oxidative stress, neurodegeneration, inflammation, apoptosis and a mitochondrial dysfunction. Recent studies have shown that vitamin D ameliorates these pathophysiologies in animal models of these diseases and in human trials $(21,24-27)$. Moreover, genetic studies on VDR SNPs have suggested the involvement of VDR in these diseases (28-33), but only limited data are available on VDR SNPs in ALS. We therefore set out to examine the possible associations between four SNPs of VDR gene and ALS.

In our study, the ApaI A allele proved to be more frequent in the ALS group than in the healthy controls, suggesting that it may have a risk effect in ALS. This work led to the first genetic evidence that the VDR gene may have a role in ALS.

Kamel et al. earlier investigated the BsmI SNP of the VDR gene, but this was not associated with the causative lead levels or ALS risk (19). We verified this observation in our study, because we did not identify a significant association with the BsmI SNP. Moreover, no significant differences were found between the other two investigated SNPs in the ALS group. 
Several studies have recently been conducted on the impact of VDR SNPs in PD. As an example, the protective or harmful roles of different SNPs of the VDR gene were examined in the Faroe Islands (where the prevalence of PD is double that in other European countries). It emerged that there were no statistical differences in genotype frequencies in the PD patients relative to the controls in the three examined SNPs (ApaI, BsmI and TaqI) (34). However, in a Chinese study Taq I seemed to be a risk factor for males with PD (31), while in a Hungarian report the Fokl $\mathrm{C}$ allele frequency was significantly higher in PD patients than in controls (32).

The associations of VDR gene SNPs with AD have been observed by three independent groups. The frequency of the Apal genotype Aa (AC genotype) was significantly higher in AD patients than in healthy individuals (29). In a comparatively large study, ApaI T and TaqI $\mathrm{G}$ were associated with the risk of $\mathrm{AD}$, particularly in patients older than 75 years (30). Preliminary evidence of interactions between the VDR SNPs (ApaI and TaqI) and the genes of interleukin 10 and dopamine- $\beta$-hydroxylase was also found. Both genes are involved in inflammation too (30).

Moreover, several SNPs were observed to be associated with the age at onset in AD or PD patients $(29,35)$. Our study did not reveal an association between the age at onset and the VDR SNPs in the ALS group.

The role of the VDR gene in MS has been only poorly investigated to date, but there are several lines of evidence which indicate that certain VDR SNPs are risk factors in MS (33). Overall, therefore, it appeared worthwhile to examine whether SNPs in the VDR gene may influence the affinity of vitamin D for its receptor, which can be related to the susceptibility to $\mathrm{PD}, \mathrm{AD}, \mathrm{MS}$ or ALS. Of course, our report has the limitation of the low sample size, but this is the first evidence that the VDR gene may have a role in ALS. Further investigations are needed to confirm our findings. 


\section{Acknowledgements}

We gratefully thank the patients and controls for participating in this study.

The study was supported by the Hungarian Brain Research Program (Grant No.

KTIA_13_NAP-A-II/17) and TÁMOP 4.2.2.A-11/1/CONV-2012-0052. 
6. Conflict of interest

The authors declare no conflicts of interest. 


\section{Author contributions}

Conceived and designed the experiments: NT, RT, and PK. Performed the experiments: NT. Selected the patients and controls, established the diagnosis, followed up the patients, and collected the samples: NT and JE. Analysed the data: NT. Wrote the paper: NT, JE, PK and LV. Study supervision and coordination: JE, PK and LV. 
References

(1) JENKINS TM, HOLLINGER H, MCDERMOTT CJ. The evidence for symptomatic treatments in amyotrophic lateral sclerosis. Curr Opin Neurol 2014; 27: 524-31.

(2) CHIO A, LOGROSCINO G, TRAYNOR BJ, et al. Global epidemiology of amyotrophic lateral sclerosis: a systematic review of the published literature. Neuroepidemiology 2013; 41: 11830.

(3) RENTON AE, CHIO A, TRAYNOR BJ. State of play in amyotrophic lateral sclerosis genetics. Nat Neurosci 2014; 17: 17-23.

(4) MARANGI G, TRAYNOR BJ. Genetic causes of amyotrophic lateral sclerosis: New genetic analysis methodologies entailing new opportunities and challenges. Brain Res 2015; 1607: 75-93.

(5) DAS A, WALLACE GT, REITER RJ, VARMA AK, RAY SK, BANIK NL. Overexpression of melatonin membrane receptors increases calcium-binding proteins and protects VSC4.1 motoneurons from glutamate toxicity through multiple mechanisms. J Pineal Res 2013; 54: 58-68.

(6) KARAM C, BARRETT MJ, IMPERATO T, MACGOWAN DJ, SCELSA S. Vitamin D deficiency and its supplementation in patients with amyotrophic lateral sclerosis. J Clin Neurosci 2013; 20: 1550-3.

(7) GIANFORCARO A, SOLOMON JA, HAMADEH MJ. Vitamin D(3) at 50x Al attenuates the decline in paw grip endurance, but not disease outcomes, in the G93A mouse model of ALS, and is toxic in females. PLoS One 2013; 8: e30243.

(8) BASIT S. Vitamin D in health and disease: a literature review. Br J Biomed Sci 2013; 70: 16172.

(9) LONG K, NGUYEN LT. Roles of vitamin D in amyotrophic lateral sclerosis: possible genetic and cellular signaling mechanisms. Mol Brain 2013; 6: 16.

(10) BROOKS BR, MILLER RG, SWASH M, MUNSAT TL. El Escorial revisited: revised criteria for the diagnosis of amyotrophic lateral sclerosis. Amyotroph Lateral Scler Other Motor Neuron Disord 2000; 1: 293-9.

(11) MILLER SA, DYKES DD, POLESKY HF. A simple salting out procedure for extracting DNA from human nucleated cells. Nucleic Acids Res 1988; 16: 1215.

(12) COLOMBINI A, BRAYDA-BRUNO M, FERINO L, et al. Gender differences in the VDR-FokI polymorphism and conventional non-genetic risk factors in association with lumbar spine pathologies in an Italian case-control study. Int J Mol Sci 2015; 16: 3722-39.

(13) NIINO M, SATO S, FUKAZAWA T, et al. Decreased serum vitamin D levels in Japanese patients with multiple sclerosis. J Neuroimmunol 2015; 279: 40-5.

(14) DUAN S, LV Z, FAN X, et al. Vitamin D status and the risk of multiple sclerosis: a systematic review and meta-analysis. Neurosci Lett 2014; 570: 108-13.

(15) SAKURAI T, OGAMA N, TOBA K. Lower vitamin D is associated with white matter hyperintensity in elderly women with Alzheimer's disease and amnestic mild cognitive impairment. J Am Geriatr Soc 2014; 62: 1993-4.

(16) LITTLEJOHNS TJ, HENLEY WE, LANG IA, et al. Vitamin D and the risk of dementia and Alzheimer disease. Neurology 2014; 83: 920-8.

(17) LIU Y, ZHANG BS. Serum 25-hydroxyvitamin D predicts severity in Parkinson's disease patients. Neurol Sci 2014; 35: 67-71.

(18) MOGHADDASI M, MAMARABADI M, AGHAII M. Serum 25-hydroxyvitamin D3 concentration in Iranian patients with Parkinson's disease. Iran J Neurol 2013; 12: 56-9.

(19) KAMEL F, UMBACH DM, LEHMAN TA, et al. Amyotrophic lateral sclerosis, lead, and genetic susceptibility: polymorphisms in the delta-aminolevulinic acid dehydratase and vitamin $D$ receptor genes. Environ Health Perspect 2003; 111: 1335-9.

(20) SOLOMON JA, GIANFORCARO A, HAMADEH MJ. Vitamin D3 deficiency differentially affects functional and disease outcomes in the G93A mouse model of amyotrophic lateral sclerosis. PLoS One 2011; 6: e29354. 
(21) GIANFORCARO A, HAMADEH MJ. Vitamin D as a potential therapy in amyotrophic lateral sclerosis. CNS Neurosci Ther 2014; 20: 101-11.

(22) SATO Y, HONDA Y, ASOH T, KIKUYAMA M, OIZUMI K. Hypovitaminosis D and decreased bone mineral density in amyotrophic lateral sclerosis. Eur Neurol 1997; 37: 225-9.

(23) TANIURA H, ITO M, SANADA N, et al. Chronic vitamin D3 treatment protects against neurotoxicity by glutamate in association with upregulation of vitamin $D$ receptor mRNA expression in cultured rat cortical neurons. J Neurosci Res 2006; 83: 1179-89.

(24) CANTORNA MT, HAYES CE, DELUCA HF. 1,25-Dihydroxyvitamin D3 reversibly blocks the progression of relapsing encephalomyelitis, a model of multiple sclerosis. Proc Natl Acad Sci U S A 1996; 93: 7861-4.

(25) WANG JY, WU JN, CHERNG TL, et al. Vitamin D(3) attenuates 6-hydroxydopamine-induced neurotoxicity in rats. Brain Res 2001; 904: 67-75.

(26) DE VIRAGH PA, HAGLID KG, CELIO MR. Parvalbumin increases in the caudate putamen of rats with vitamin D hypervitaminosis. Proc Natl Acad Sci U S A 1989; 86: 3887-90.

(27) SONI M, KOS K, LANG IA, JONES K, MELZER D, LLEWELLYN DJ. Vitamin D and cognitive function. Scand J Clin Lab Invest Suppl 2012; 243: 79-82.

(28) WANG L, HARA K, VAN BAAREN JM, et al. Vitamin D receptor and Alzheimer's disease: a genetic and functional study. Neurobiol Aging 2012; 33: 1844 e1-9.

(29) GEZEN-AK D, DURSUN E, ERTAN T, et al. Association between vitamin D receptor gene polymorphism and Alzheimer's disease. Tohoku J Exp Med 2007; 212: 275-82.

(30) LEHMANN DJ, REFSUM H, WARDEN DR, MEDWAY C, WILCOCK GK, SMITH AD. The vitamin D receptor gene is associated with Alzheimer's disease. Neurosci Lett 2011; 504: 79-82.

(31) LIU HX, HAN X, ZHENG XP, LI YS, XIE AM. [Association of vitamin D receptor gene polymorphisms with Parkinson disease]. Zhonghua Yi Xue Yi Chuan Xue Za Zhi 2013; 30: 13-6.

(32) TOROK R, TOROK N, SZALARDY L, et al. Association of vitamin D receptor gene polymorphisms and Parkinson's disease in Hungarians. Neurosci Lett 2013; 551: 70-4.

(33) TIZAOUI K, KAABACHI W, HAMZAOUI A, HAMZAOUI K. Association between vitamin D receptor polymorphisms and multiple sclerosis: systematic review and meta-analysis of casecontrol studies. Cell Mol Immunol 2015; 12: 243-52.

(34) PETERSEN MS, BECH S, CHRISTIANSEN DH, SCHMEDES AV, HALLING J. The role of vitamin D levels and vitamin $D$ receptor polymorphism on Parkinson's disease in the Faroe Islands. Neurosci Lett 2014; 561: 74-9.

(35) HAN X, XUE L, LI Y, CHEN B, XIE A. Vitamin D receptor gene polymorphism and its association with Parkinson's disease in Chinese Han population. Neurosci Lett 2012; 525: 29-33. 
Tables

Table 1. Summary of the sociodemographic data

\begin{tabular}{|l|c|c|c|c|c|c|c|c|}
\hline Groups & Males & Females & $\begin{array}{c}\text { Mean age } \\
\text { (SD) (years) }\end{array}$ & Median & Min & Max & $\begin{array}{c}\text { Age at onset } \\
\text { (SD) (years) }\end{array}$ & $\begin{array}{c}\text { Median } \\
\text { of the } \\
\text { age at } \\
\text { onset }\end{array}$ \\
\hline $\begin{array}{l}\text { ALS } \\
\text { patients } \\
(74)\end{array}$ & 28 & 47 & $60.3 \pm 11.0$ & 61 & 33 & 86 & $58.9 \pm 11.8$ & 60 \\
\hline $\begin{array}{l}\text { Controls } \\
(97)\end{array}$ & 36 & 61 & $60.1 \pm 11.3$ & 62 & 33 & 84 & - & - \\
\hline
\end{tabular}

Min: minimum age in the group, Max: maximum age in the group, SD: standard deviation 
Table 2. Genotype distributions of the VDR gene in the ALS and control groups

\begin{tabular}{|c|c|c|c|c|c|c|c|}
\hline Groups & \multicolumn{3}{|c|}{ Genotype } & & \multicolumn{2}{|c|}{ Allele frequency } & \\
\hline $\begin{array}{l}\text { rs } 1544410 \\
(\mathrm{BsmI})\end{array}$ & $\mathrm{AA}(\%)$ & $\mathrm{AG}(\%)$ & GG $(\%)$ & $\mathrm{p}$ & $\mathrm{A}(\%)$ & $\mathrm{G}(\%)$ & $\mathrm{p}$ \\
\hline ALS & $\begin{array}{c}9 \\
(12 \%)\end{array}$ & $\begin{array}{c}35 \\
(46.7 \%)\end{array}$ & $\begin{array}{c}31 \\
(41.3 \%)\end{array}$ & \multirow[b]{2}{*}{0.327} & $\begin{array}{c}53 \\
(35.3 \%)\end{array}$ & $\begin{array}{c}97 \\
(64.7 \%)\end{array}$ & \multirow{2}{*}{0.527} \\
\hline Controls & $\begin{array}{c}19 \\
(19.6 \%)\end{array}$ & $\begin{array}{c}37 \\
(38.1 \%)\end{array}$ & $\begin{array}{c}41 \\
(42.3 \%)\end{array}$ & & $\begin{array}{c}75 \\
(38.7 \%)\end{array}$ & $\begin{array}{c}119 \\
(61.3 \%)\end{array}$ & \\
\hline $\begin{array}{l}\text { Age at onset } \\
\leq 60 \text { years }\end{array}$ & $\begin{array}{c}3 \\
(7.9 \%) \\
\end{array}$ & $\begin{array}{c}16 \\
(42.1 \%)\end{array}$ & $\begin{array}{c}19 \\
(50 \%)\end{array}$ & \multirow{2}{*}{0.244} & & & \\
\hline $\begin{array}{l}\text { Age at onset } \\
>60 \text { years }\end{array}$ & $\begin{array}{c}6 \\
(16.2 \%)\end{array}$ & $\begin{array}{c}19 \\
(51.4 \%)\end{array}$ & $\begin{array}{c}12 \\
(32.4 \%)\end{array}$ & & & & \\
\hline Male & $\begin{array}{c}5 \\
(17.9 \%) \\
\end{array}$ & $\begin{array}{c}16 \\
(57.1 \%) \\
\end{array}$ & $\begin{array}{c}7 \\
(25 \%) \\
\end{array}$ & \multirow{2}{*}{0.074} & & & \\
\hline Female & $\begin{array}{c}4 \\
(8.6 \%)\end{array}$ & $\begin{array}{c}19 \\
(40.4 \%)\end{array}$ & $\begin{array}{c}24 \\
(51 \%)\end{array}$ & & & & \\
\hline $\begin{array}{l}\text { rs7975232 } \\
\text { (ApaI) }\end{array}$ & $\mathrm{AA}(\%)$ & $\mathrm{AC}(\%)$ & $\mathrm{CC}(\%)$ & $\mathrm{p}$ & $\mathrm{A}(\%)$ & $\mathrm{C}(\%)$ & $\mathrm{p}$ \\
\hline ALS & $\begin{array}{c}25 \\
(33.3 \%)\end{array}$ & $\begin{array}{c}43 \\
(57.3 \%)\end{array}$ & $\begin{array}{c}7 \\
(9.3 \%)\end{array}$ & \multirow{2}{*}{0.004} & $\begin{array}{c}93 \\
(62 \%)\end{array}$ & $\begin{array}{c}57 \\
(38 \%)\end{array}$ & \multirow{2}{*}{0.021} \\
\hline Controls & $\begin{array}{c}28 \\
(28.9 \%) \\
\end{array}$ & $\begin{array}{c}40 \\
(41.2 \%) \\
\end{array}$ & $\begin{array}{c}29 \\
(29.9 \%) \\
\end{array}$ & & $\begin{array}{c}96 \\
(49.5 \%) \\
\end{array}$ & $\begin{array}{c}98 \\
(50.5 \%) \\
\end{array}$ & \\
\hline $\begin{array}{l}\text { Age at onset } \\
\leq 60 \text { years }\end{array}$ & $\begin{array}{c}10 \\
(26.3 \%)\end{array}$ & $\begin{array}{c}23 \\
(60.5 \%)\end{array}$ & $\begin{array}{c}5 \\
(13.2 \%)\end{array}$ & \multirow{2}{*}{0.289} & & & \\
\hline $\begin{array}{l}\text { Age at onset } \\
>60 \text { years }\end{array}$ & $\begin{array}{c}15 \\
(41 \%)\end{array}$ & $\begin{array}{c}20 \\
(54 \%)\end{array}$ & $\begin{array}{c}2 \\
(5 \%)\end{array}$ & & & & \\
\hline Male & $\begin{array}{c}12 \\
(42.9 \%) \\
\end{array}$ & $\begin{array}{c}13 \\
(46.4 \%) \\
\end{array}$ & $\begin{array}{c}3 \\
(10.7 \%) \\
\end{array}$ & \multirow{2}{*}{0.327} & & & \\
\hline Female & $\begin{array}{c}13 \\
(27.7 \%)\end{array}$ & $\begin{array}{c}30 \\
(63.8 \%)\end{array}$ & $\begin{array}{c}4 \\
(8.5 \%)\end{array}$ & & & & \\
\hline $\begin{array}{l}\text { rs731236 } \\
\text { (TaqI) }\end{array}$ & $\mathrm{CC}(\%)$ & CT (\%) & $\mathrm{TT}(\%)$ & $\mathrm{p}$ & $\mathrm{C}(\%)$ & $\mathrm{T}(\%)$ & $\mathrm{p}$ \\
\hline ALS & $\begin{array}{c}9 \\
(12 \%)\end{array}$ & $\begin{array}{c}34 \\
(45 \%)\end{array}$ & $\begin{array}{c}32 \\
(43 \%)\end{array}$ & \multirow{2}{*}{0.462} & $\begin{array}{c}52 \\
(34.7 \%)\end{array}$ & $\begin{array}{c}98 \\
(65.3 \%) \\
\end{array}$ & \multirow{2}{*}{0.507} \\
\hline Controls & $\begin{array}{c}18 \\
(18.6 \%)\end{array}$ & $\begin{array}{c}38 \\
(39.2 \%)\end{array}$ & $\begin{array}{c}41 \\
(42.3 \%) \\
\end{array}$ & & $\begin{array}{c}74 \\
(38.1 \%)\end{array}$ & $\begin{array}{c}120 \\
(61.9 \%)\end{array}$ & \\
\hline $\begin{array}{l}\text { Age at onset } \\
\leq 60 \text { years }\end{array}$ & $\begin{array}{c}3 \\
(7.9 \%) \\
\end{array}$ & $\begin{array}{c}16 \\
(42.1 \%) \\
\end{array}$ & $\begin{array}{c}19 \\
(50 \%)\end{array}$ & \multirow{2}{*}{0.328} & & & \\
\hline $\begin{array}{l}\text { Age at onset } \\
>60 \text { years }\end{array}$ & $\begin{array}{c}6 \\
(16.2 \%)\end{array}$ & $\begin{array}{c}18 \\
(48.7 \%) \\
\end{array}$ & $\begin{array}{c}13 \\
(35.1 \%) \\
\end{array}$ & & & & \\
\hline Male & $\begin{array}{c}5 \\
(17.9 \%) \\
\end{array}$ & $\begin{array}{c}15 \\
(53.6 \%)\end{array}$ & $\begin{array}{c}8 \\
(28.6 \%)\end{array}$ & \multirow{2}{*}{0.134} & & & \\
\hline Female & $\begin{array}{c}4 \\
(8.5 \%)\end{array}$ & $\begin{array}{c}19 \\
(40.4 \%)\end{array}$ & $\begin{array}{c}24 \\
(51.1 \%) \\
\end{array}$ & & & & \\
\hline
\end{tabular}




\begin{tabular}{|c|c|c|c|c|c|c|c|}
\hline $\begin{array}{l}\text { rs2228570 } \\
\text { (FokI) }\end{array}$ & $\mathrm{CC}(\%)$ & CT (\%) & TT (\%) & $\mathrm{p}$ & $\mathrm{C}(\%)$ & $\mathrm{T}(\%)$ & $\mathrm{p}$ \\
\hline ALS & $\begin{array}{c}30 \\
(40 \%) \\
\end{array}$ & $\begin{array}{c}35 \\
(46.7 \%) \\
\end{array}$ & $\begin{array}{c}10 \\
(13.3 \%) \\
\end{array}$ & \multirow{2}{*}{0.801} & $\begin{array}{c}95 \\
(63.3 \%) \\
\end{array}$ & $\begin{array}{c}55 \\
(36.7 \%) \\
\end{array}$ & \multirow{2}{*}{0.542} \\
\hline Controls & $\begin{array}{c}42 \\
(43.3 \%)\end{array}$ & $\begin{array}{c}45 \\
(46.4 \%)\end{array}$ & $\begin{array}{c}10 \\
(10.3 \%)\end{array}$ & & $\begin{array}{c}129 \\
(66.5 \%)\end{array}$ & $\begin{array}{c}65 \\
(33.5 \%)\end{array}$ & \\
\hline $\begin{array}{l}\text { Age at onset } \\
\leq 60 \text { years }\end{array}$ & $\begin{array}{c}17 \\
(44.7 \%) \\
\end{array}$ & $\begin{array}{c}18 \\
(47.4 \%) \\
\end{array}$ & $\begin{array}{c}3 \\
(7.9 \%) \\
\end{array}$ & \multirow{2}{*}{0.341} & & & \\
\hline $\begin{array}{l}\text { Age at onset } \\
>60 \text { years }\end{array}$ & $\begin{array}{c}13 \\
(35.1 \%) \\
\end{array}$ & $\begin{array}{c}17 \\
(46 \%) \\
\end{array}$ & $\begin{array}{c}7 \\
(18.9 \%) \\
\end{array}$ & & & & \\
\hline Male & $\begin{array}{c}11 \\
(39.3 \%) \\
\end{array}$ & $\begin{array}{c}13 \\
(46.4 \%) \\
\end{array}$ & $\begin{array}{c}4 \\
(14.3 \%) \\
\end{array}$ & \multirow{2}{*}{0.982} & & & \\
\hline Female & $\begin{array}{c}19 \\
(40.4 \%)\end{array}$ & $\begin{array}{c}22 \\
(46.8 \%)\end{array}$ & $\begin{array}{c}6 \\
(12.8 \%)\end{array}$ & & & & \\
\hline
\end{tabular}


Figures

Figure 1. Gel electrophoresis images of the four investigated SNPs

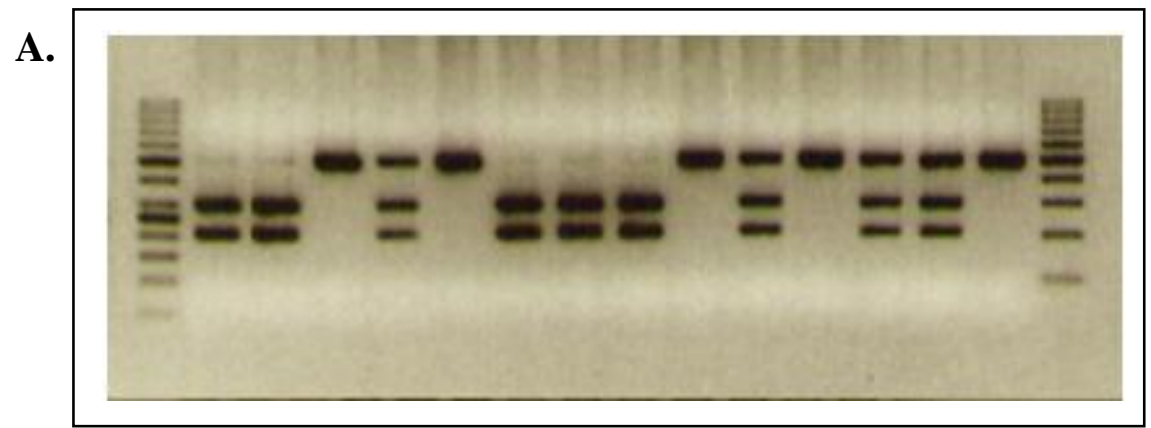

B.

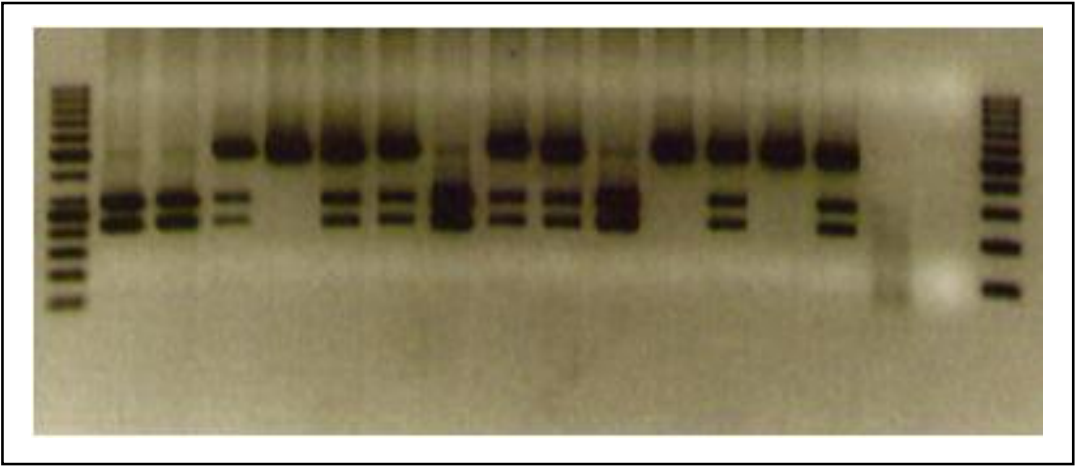

C.

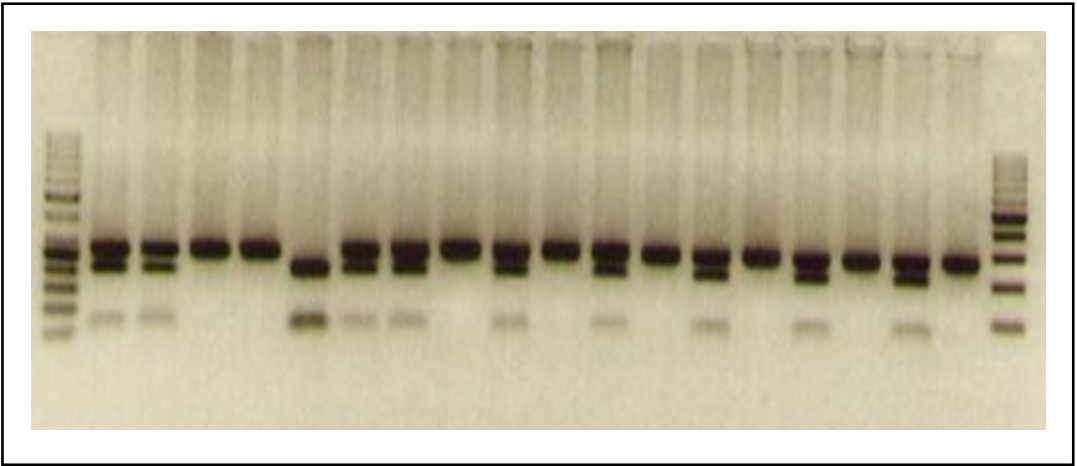

D.

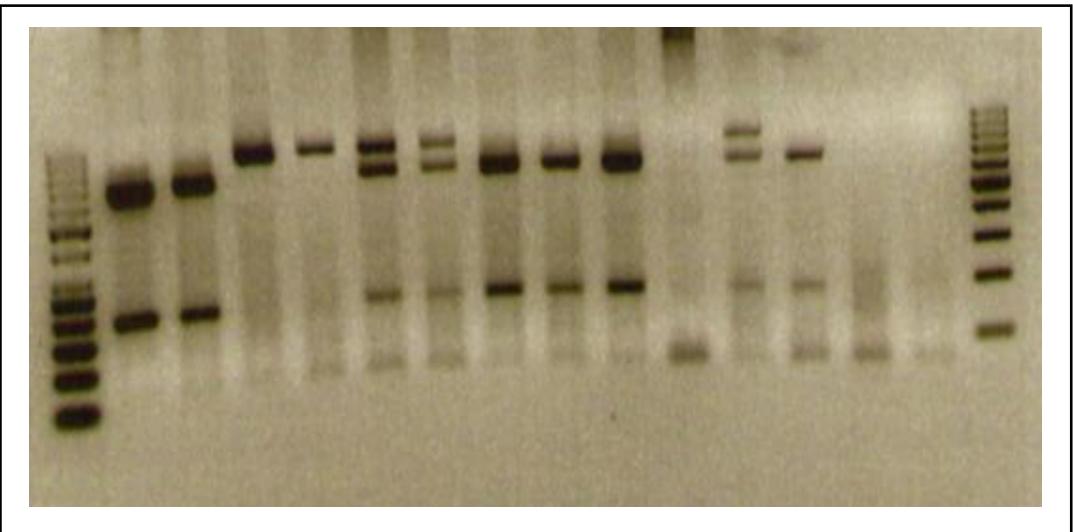

Figure legend:

A. TaqI: CC: 293 bp, 201 bp, 7 bp; CT: 494 bp, 293 bp, 201 bp, 7 bp; TT: 494 bp, 7 bp

B. ApaI: CC: 284 bp, 217 bp; AC: 501 bp, 284 bp, 217 bp; AA: 501 bp 
C. FokI: CC: 267 bp; CT: 267 bp, 207 bp, 60 bp; TT: 207 bp, 60 bp

D. BsmI: AA: 822 bp; AG: 822 bp, 646 bp, 176 bp; GG: 646 bp, 176 bp

We used Gene Ruler $50 \mathrm{bp}$ (left side) and the $100 \mathrm{bp}$ (right side) DNA ladders from the

Thermo Scientific. 
Figure 2. Distribution of the ApaI A allele in the ALS patient and control groups

Distribution of the Apal A allele

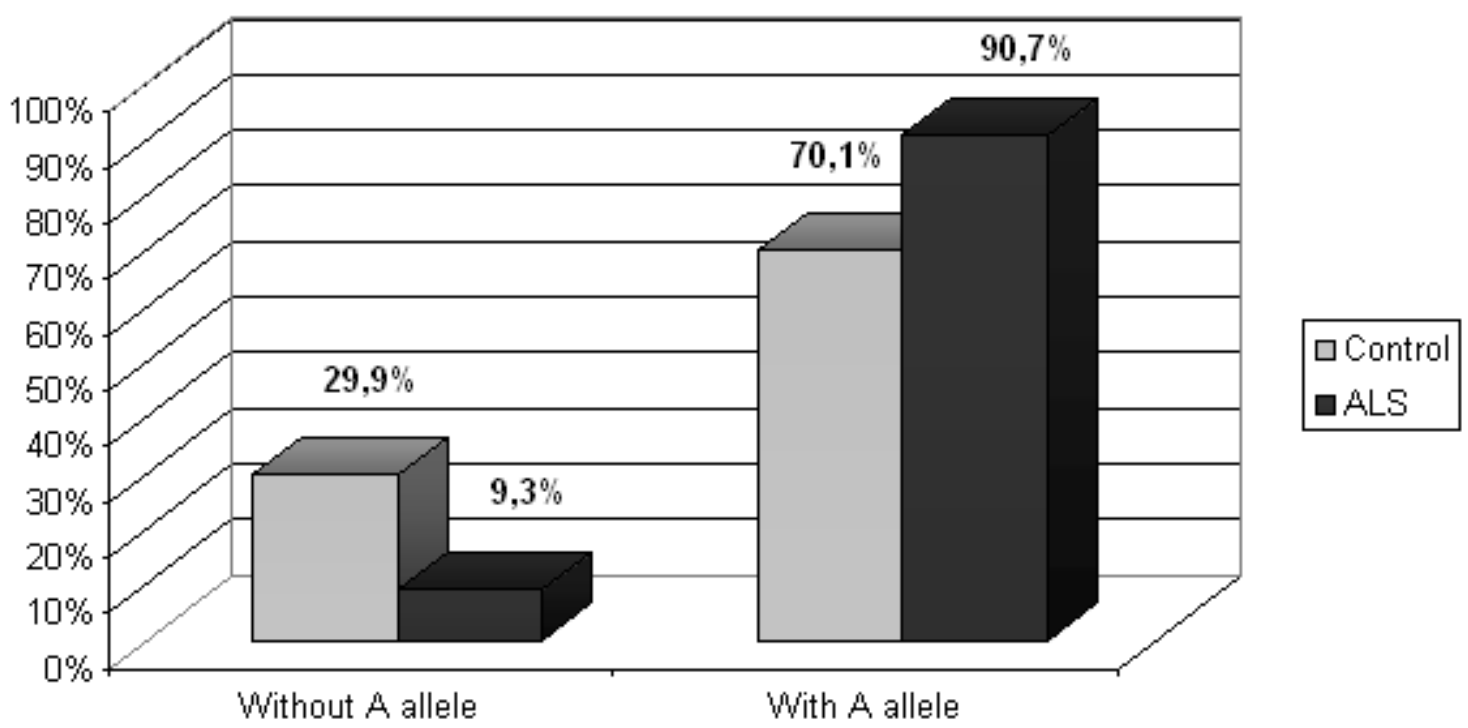

Figure legend:

Figure shows the difference in distribution (in percentage) of the ApaI A allele between the patient and control groups. The frequency of the genotype with $\mathrm{A}(\mathrm{AA}+\mathrm{AC})$ was significantly higher in the ALS patients than in the controls $(\chi 2=10.807, \mathrm{df}=1, \mathrm{p}=0.001, \mathrm{OR}: 4.143$ and 95\% CI=1.699-10.100) for AA+AC vs CC), while without the A allele the ratio was opposite. 